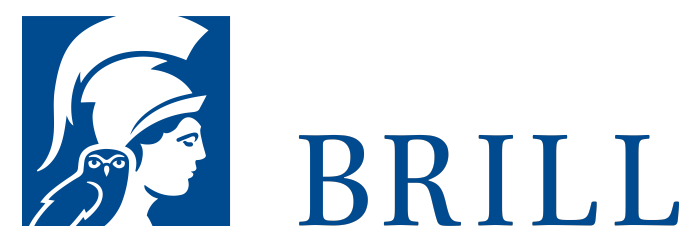

\title{
Goethe im Spätwerk
}

Glaube - Weltsicht - Ethos

Author: Wilhelm Flitner

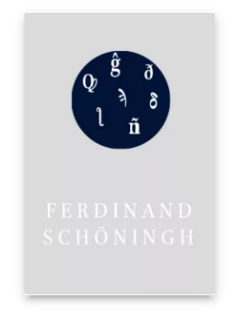

Published: 22 Nov 1983

Pages: 363 Seiten

Subjects:

General, Education

Publisher: Brill | Schöningh

Series:

Wilhelm Flitner, Gesammelte Schriften, Volume: 6

Paperback ISBN: 978-35०6-72566-о Price:

[USS] \$107.00 
Please send your order to: Brockhaus/Commission Tel: +49(o)71 541327 9216 | E-Mail: brill@ $\underline{\text { brocom.de }}$

For questions please contact: Brill Deutschland GmbH

Wollmarktstraße 115 | 33098 Paderborn | Germany

Tel: +49 (o)5251 69975 o | E-Mail: sales@brill.com. 